УДК 341.123

DOI https://doi.org/10.32849/2663-5313/2020.4.66

Орина Курило,

студентка Інституту прокуратури та кримінальної юстиціі

Начіонального юридичного університету імені Ярослава Мудрого

\title{
ПРАВО НА СПРАВЕДЛИВИЙ СУД У ПРАКТИЦІ ЄВРОПЕЙСЬКОГО СУДУ 3 ПРАВ ЛЮДИНИ
}

Стаття присвячена висвітленню ролі і значення Конвениії про захист прав людини і основоположних свобод (далі - Конвенція) в національному законодавстві України. Розкрито основне положення статті 6 иієї Конвениії, в якому визначається право кожного на справедливий і публічний розгляд його справи. Оскільки ие питання досить багатогранне і може трактуватися по-різному, необхідним є дослідження його з точки зору практики Європейського Суду з прав людини. Саме він встановлює необхідні та обов'язкові до виконання стандарти забезпечення дотримання прав і свобод людини державами-учаснииями Конвениії. У статті розглядається рішення Європейського Суду з прав людини, що наголошує на необхідності створення на нащіональному рівні умов для безперешкодного доступу до правосуддя, виділяються його основні аспекти. Розглядаються основні питання, що пов'язані із невідповідністю українського законодавства передбаченим статтею 6 Конвениіі гарантіям права на доступ до правосуддя з питань юридичного аспекту, а саме зависоких розмірів судових витрат, пов'язаних із проведенням експертиз і залученням спеиіалістів. Автором статті запропоновані основні шляхи подолання иієї проблеми. А обгрунтована необхідність розширення кола осіб, яким може надаватися безоплатна вторинна правова допомога поза сферою кримінального судочинства. Також не оминули увагою застосування приниипу публічності розгляду справи з питань втручання засобів масової інформації в правоохоронну і судову діяльність. Розкрили основні питання, пов'язані із необхідністю офічійного або ж просто достовірного перекладу рішень Свропейського Суду з прав людини, ухвалених проти інших держав, оскільки вони так само є допоміжним джерелом права і активно застосовуються як правозахисниками, так і суддями. Запропоновано ідею впровадження на законодавчому рівні можливості надання лічензій для здійснення діяльності, пов'язаної із забезпеченням держави достовірним і повним перекладом рімень Європейського Суду з прав людини.

Ключові слова: принцип публічності, Конвенція про захист прав людини і основоположних свобод, національне законодавство, міжнародні стандарти, доступність правосуддя, безоплатна вторинна правова допомога.

Постановка проблеми. Конвенція про захист прав людини і основоположних свобод натепер відіграє вирішальну роль у правовій системі будь-якої держави. Проте сама по собі вона втілює у собі основоположні принципи та ідеали, до яких мають прагнути всі держави-учасниці цієї Конвенції, а тлумачення її норм для однакового їх застосування здійснюється Європейським Судом 3 прав людини (далі - ССПЛ). Стаття 6 Конвенції закріплює за кожною особою право на «справедливий і публічний розгляд іiі справи, упродовж розумного строку незалежним і безстороннім судом, встановленим законом» [1] та низку інших прав особи. Але поняття «справедливий суд», «розумні строки», «час і можливості, необхідні для підготовки свого захисту» - це все певною мірою оціночні поняття, які кожна особа може трактувати по-своєму залежно від її правової свідомості, культури і моральних переконань. А тому рішення ССПЛ відіграють важливу роль у формуванні єдиної практики як на міжнародному, так і на національному рівнях. Але і досі не впроваджено механізму, який забезпечив би переклад рішень ЄСПЛ, винесених не проти України. Також важливими є питання доступності правосуддя та публічного розгляду справ. Але, на жаль, сучасне українське законодавство не повною мірою реалізує ці аспекти права на справедливий суд.

Аналіз останніх досліджень і публікацій. В умовах українського курсу на євроінтеграцію, зростаючої ролі Конвенції та обов'язковості практики ЄСПЛ усе більше вчених займаються дослідженням норм цієї Конвенції, можливості і доцільності їх застосування у сучасному законодавстві. Серед них можна зазначити В. Абдрашитову, Е. Алисиевич, Л. Вильдхабера, С. Васильєву, О. Гаврилюк, В. Комарова, О. Лисенкова, В. Туманова, Т. Фулей, I. Яковюка та інших. Проте питання саме проблемності застосування положень статті 6 Конвенції на практиці залишається малодослідженим. 
Як і можливість застосування положень статті 6 Конвенції, перекладу яких українською мовою немає

Мета статті - розкрити основні недоліки і проблеми практичного забезпечення української спільноти правом на справедливий суд у національному судочинстві; визначити, як саме ці проблеми можуть бути вирішені і які можуть бути механізми удосконалення національної правової системи.

Виклад основного матеріалу. Загалом, право на справедливий суд є одним із основоположних прав людини, бо якщо не діє правова конструкція цієї норми, то всі останні права людини залишаються не захищені, взагалі немає ніякої гарантії на якісне та безстороннє судочинство. Так, ще у 1975 р. була досить гучна справа ЄСПЛ 3 приводу захисту першочергового права у контексті загального права на справедливий суд - це право на доступ до суду у справі «Голдер проти Великої Британії» [2]. У цій справі ЄСПЛ зазначає, що сама модель права на справедливий суд була би жалюгідною та безглуздою, якби ця норма не забезпечувала право на те, що твоя справа взагалі буде розглянутою. Тобто у цій справі ЄСПЛ констатує, що право на справедливість - це багатогранне поняття, яке перш за все має надавати людям доступ до суду як безперешкодну можливість захисту своїх прав без проходження спеціальних оплатних процедур, без отримування спеціальних дозволів на тій же основі чи інших обтяжень до позивача. Також у цьому елементі права на справедливий суд необхідно зазначити правову позицію ЄСПЛ у справі «Ейрі проти Ірландії [3]. Там ЄСПЛ зазначив, що право на справедливий суд може бути порушене як фактичними перешкодами, так і юридичними. 3 приводу цього ЄСПЛ вказав, що Конвенція служить гарантією не теоретичних прав, які нормативно закріплені, але залишаються мертвими нормами, а прав, які є ефективними для захисту прав людини саме на практиці. Звідси стає зрозумілим, що для нормального забезпечення права на доступ до правосуддя як складової частини права на справедливий суд необхідні такі елементи, як процесуальні та фізичні можливості звернення до суду. Також у контексті забезпечення нормального доступу до суду не можливо не згадати економічні перепони, котрі, незважаючи на формально визначену можливість доступу, створюють проблеми в матеріальному плані. I це є найбільшою перепоною саме для адміністративного та цивільного судочинства. Зокрема, високі рівні судових зборів за право розгляду твого позову, судових витрат, у тому числі на виклик свідків, проведення експертиз тощо. На підтвердження цього можна зазначити, що провести посмертну судово-психіатричну експертизу 3 метою встановлення психічного стану особи на момент вчинення тих чи інших дій коштуватиме понад 20000 грн. У цьому питанні, на мій погляд, можливо, краще було би на законодавчому рівні змінити підхід законодавця до розподілу судових витрат, зокрема в адміністративному судочинстві, оскільки там особа звертається для суду з метою поновлення порушених державою чи органами місцевого самоврядування прав. Але вона банально не може оплатити проведену експертизу. Окрім судового збору, до економічних перепон можна віднести неможливість оплатити юридичні послуги адвоката. Але тут слід мати на увазі не кримінальні справи, оскільки в п. с ч. 3 ст. 6 Конвенції прямо зазначено, що у кримінальному судочинстві держава зобов'язана надати безоплатну правову допомогу. Але, окрім кримінальних справ, є ще інші види судочинства, в яких необхідним $є$ захисник, з оплатою якого пересічні громадяни не завжди в змозі впоратися. Так, у нас $є$ інститут безоплатної вторинної правової допомоги, але право на нього відповідно до п. 1 ч. 1 ст. 14 Закону України «Про безоплатну правову допомогу» мають особи, які перебувають під юрисдикцією України, якщо їхній середньомісячний дохід не перевищує двох розмірів прожиткового мінімуму, розрахованого та затвердженого відповідно до закону для осіб, які належать до основних соціальних і демографічних груп населення [4]. Натепер прожитковий мінімум відповідно до ст. 7 Закону України «Про державний бюджет України на 2020 рік» становить 2102 грн [5]. Отже, можемо дійти висновку, що право на безоплатну правову допомогу має кожний, чий середньомісячний заробіток не перевищує 4204 грн. А що робити тим, хто отримує 5000-6000 грн у місяць? Чи можуть вони дозволити собі оплачувати послуги адвоката в цивільному чи адміністративному судочинстві? Чи можна стверджувати, що в них є доступ до правосуддя? На мою думку, ні. Саме тому національне законодавство потребує внесення змін, розширення кола суб'єктів, на яких поширюється можливість отримання безоплатної вторинної правової допомоги. А також залучати більше адвокатів і юристів до надання такої допомоги населенню.

Далі слід розглянути наступний, більшменш важливий елемент права на справедливий суд - це публічний судовий розгляд. Всім відомо, що принцип публічного розгляду справи у суді - це положення 
ст. 6 Конвенції, згідно з яким під час судового розгляду певної справи до зали суду мають доступ не тільки сторони чи зацікавлені особи, але і будь-яка стороння людина або група людей. Традиційно прийнято вважати, що публічність під час здійснення судочинства - це один 3 найголовніших принципів для побудови та функціонування правосуддя. Так, з цим можна погодитись, але в цьому є і темна сторона, яка, наприклад, у вітчизняному законодавстві врегульована, але в деяких країнах ще залишається актуальною до теперішнього часу. Так, відомо, що задля забезпечення гласності судового процесу пересічні громадяни мають право бути поінформованими про хід певного судового процесу, звідси реалізація цього принципу вимагає взаємодії засобів масової інформації (далі - 3МI) із судовими органами. Тут вважаю за необхідне зазначити правову позицію Верховного Суду США, він зазначає, що зловживання свободою слова з боку ЗМІ може призвести до негативних наслідків, зокрема, до неповаги до суду або розголошення таємниці слідства. На мій погляд, це досить дискусійне твердження, оскільки, по-перше, слід ураховувати, хто є сторонами процесу, наприклад якщо однією зі сторін судового розгляду $€$ представник політичної середи держави, то таке «зловживання», навпаки, має місце, підтвердженням цьому є справа ЄСПЛ «Лінгенс проти Австрії» [6]. У цій справі ЄСПЛ зазначає, що вимоги плюралізму, толерантності і лібералізму, на яких грунтується «демократичне суспільство», набувають особливого значення в тому, що стосується преси. Саме на неї покладена місія з поширення інформації та ідей з політичних питань. Якщо на пресу покладено завдання повідомляти таку інформацію та ідеї, то громадськість, зі свого боку, має право отримувати їх. Також ЄСПЛ зазначив, що межі допустимої критики щодо політиків як таких ширші, ніж стосовно приватної особи. На відміну від останньої, перший має проявляти велику терпимість до пильної уваги журналістів і всього суспільства до кожного його слова і дій, зокрема під час судового процесу. I це, на мій погляд, виправдано, бо поведінка політичного лідера, його слова і вчинки, його позиція і рішення, на відміну від приватної особи, впливають на життя великої кількості людей, а також усього народу. Цю тезу також підтверджує ЄСПЛ, він зазначає, що взявши на себе відповідальність за долю країни і народу, лідер тим самим поставив себе під соціальний контроль, і суспільство має право знати, куди приведе такий лідер свій народ. 3 огляду на все вищесказане, можна констатувати, що зловживання 3МІ правом на публічний роз- гляд здебільшого необхідне. Але ж не можна не погодитись 3 тим, що надмірна увага ЗМІ до процесу досудового розслідування в намаганні знайти найсвіжіші і найзахоплюючі кадри може негативно впливати на сам хід досудового розслідування. Так, репортери можуть видати факти, якими оперує слідство, або ж повідомити про те, що почалася кампанія проти певної злочинної організації. Тож у певних випадках необхідно створити обмеження саме для доступу журналістів до місця злочину.

Наступним важливим питанням є застосування статті 6 Конвенції до адміністративного судочинства. Так, норма закріплює: «Кожен має право на справедливий і публічний розгляд його справи упродовж розумного строку незалежним і безстороннім судом, встановленим законом, який вирішить спір щодо його прав та обов'язків цивільного характеру або встановить обгрунтованість будь-якого висунутого проти нього кримінального обвинувачення». Зі змісту норми ми чітко можемо зрозуміти сферу застосування права на справедливий суд - кримінальне і цивільне судочинство. Але ж відомі рішення ССПЛ проти України, в яких порушення цієї статті констатували i в адміністративному судочинстві. Прикладом цього є справа «Олександр Волков проти України» [7], де суд визнав порушення ст. 6 Конвенції у частині розгляду справи незалежним і безстороннім судом, встановленим законом, незважаючи на те, що справа заявника розглядалася спочатку Вищою радою юстиції України, а потім Вищим Адміністративним Судом України. Чи можна це назвати відступом від положень, встановлених Конвенцією? На мою думку, ні. Оскільки це є прикладом того, наскільки є важливою практика ЄСПЛ стосовно тлумачення і роз'яснення положень Конвенції, деталізації і розкриття їх змісту. Проте стосовно цього є інша проблема недоступність судових рішень, щодо яких немає офіційного перекладу. Так, рішення проти України перекладаються українською мовою. Але ж як бути з іншими рішеннями, які можуть містити важливу інформацію з приводу застосування тих чи інших положень Конвенції? Для цього можна запровадити ліцензійну діяльність, яка полягатиме у наданні державою ліценцій на здійснення перекладу пілотних рішень ЄСПЛ. Тоді буде повною мірою забезпечуватись право на справедливий суд, оскільки положення Конвенції будуть тлумачитись у рішеннях ЄСПЛ національною мовою, що виключатиме двозмістовність і певні неточності перекладу. 


\section{Висновки}

Право на справедливий суд є основоположним правом кожної людини, закріпленим у Конвенції і уточненим у рішеннях ЄСПЛ. Проте, навіть попри це, в українському законодавстві не досить правових засобів його реалізації, а це дає простір для удосконалення національного законодавства. Зокрема, необхідним є внесення змін до Закону України «Про безоплатну правову допомогу», перегляд принципу публічності, визначеного у національному законодавстві ною діяльністю та необхідністю прийняття закону, який би вирішив питання із застосуванням практики ССПЛ в аспекті рішень, які не перекладені українською мовою.

\section{Список використаних джерел:}

1. Конвенція про захист прав людини і основоположних свобод, ратифікована Законом України № 475/97-ВР від 17.07.1997 року. Чинна. щодо його співвідношення 3 правоохорон-

В редакції від 1.05.2004 року. URL: https:// zakon.rada.gov.ua/laws/show/995 004\#n42.

2. Справа Голдер (Golder) проти Об'єднаного Королівства. Рішення Європейського Суду з прав людини від 21.02.1975 року. URL: https:// zakon.rada.gov.ua/laws/show/980 086.

3. Справа Єйрі проти Ірландії. Рішення Європейського Суду з прав людини від 09.10.1979 року. URL: https://zakon.rada.gov.ua/laws/show/980 332.

4. Про безоплатну правову допомогу : Закон України № 3460-VI від 02.06.2011 року. Чинний. Поточна редакція від 16.01.2020 року. URL https://zakon.rada.gov.ua/laws/show/3460-17.

5. Про Державний бюджет України на 2020 рік : Закон України № 294-IX від 14.11.2019 року. Чинний. Поточна редакція від 17.03.2020 року. URL https://zakon.rada.gov.ua/laws/show/294-IX.

6. Справа Лінгенс проти Австрії. Рішення Європейського Суду з прав людини від 08.07.1986 року. URL: https://zakon.rada.gov.ua/laws/show/980 066

7. Справа Олександр Волков проти України. Рішення Європейського Суду з прав людини від 09.01.2013 року. URL: https://zakon.rada.gov.ua/ laws/show/974 947.

The article describes the role and importance of the Convention for the Protection of Human Rights and Fundamental Freedoms (hereinafter - the Convention) in the national Ukrainian's legislation. The main position of Article 6 of this Convention, which sets out the right of everyone to a fair and public hearing, is disclosed in the article. Since this issue is multifaceted and may be interpreted differently, it is necessary to examine it from the point of view of the case law of the European Court of Human Rights. It sets the necessity and binding standards for the enforcement of human rights and freedoms by the parties of the Convention. The article examines the decision of the European Court of Human Rights, which emphasizes the need to create at the national level conditions for unhindered access to justice, its main aspects are highlighted by the author. The main issues related to the incompatibility of Ukrainian law with Article 6 of the Convention are guaranteed by the guarantees of the right of access to justice on legal issues, namely the overly high costs of legal fees related to the examination and involvement of specialists. The author of the article suggests the main ways to overcome this problem. And the necessity of expansion the range of laweyers, who can be provided with free secondary legal assistance outside the sphere of criminal justice is justified. Also, the applying of the principle of publicity of the case concerning the interference of the media in law enforcement and judicial activity was not overlooked. What is more, the author of the article has raised the main issues related to the need for an official orjust authentic translation of the decisions of the European Court of Human Rights against other states, as they are also an auxiliary source of law and are actively used by human rights defenders and judges. The ide of introducing at the legislative level the possibility of granting licenses to carry out activities related to the procuring of the state by a reliable and complete translation of the decisions of the European Court of Human Rights.

Key words: principle of publicity, Convention for the Protection of Human Rights and Fundamental Freedoms, national legislation, international standards, accessibility of justice, chargeless secondary legal assistance. 